\title{
Viable Antimicrobial Resistant Bacteria are Transported from Cattle Feed Yards via Aerosolized Particulate Matter
}

\begin{abstract}
Keywords: Antimicrobial; Resistance; Cattle; Feed yard; Particulate matter; Dust

Abstract

Increased awareness of consequences associated with Antimicrobial Resistant Bacteria (ARB) has given rise to considerable research on how and where resistance to antimicrobial agents occurs. A recent investigation that utilized DNA sequencing-based technologies to characterize bacterial communities suggests that ARBs are generated on cattle feed yards and dispersed into the environment via wind-blown Particulate Matter (PM). Despite compelling evidence that bacterial DNA was prominent in fugitive PM, it remained unclear whether the bacterial DNA was derived from viable microorganisms. Thus, the narrow focus of this investigation was to determine whether bacteria associated with airborne PM emanating from cattle feed yards are viable, and if so, whether any cultivable bacteria were resistant to antibiotics. Numerous viable aerobic, microaerophilic, and anaerobic bacteria were successfully cultured from aerosolized, feed yardderived PM. Several cultured isolates were resistant to an assortment of antibiotics. This confirms that viable antimicrobial resistant bacteria do indeed travel on airborne PM emanating from cattle feed yards.
\end{abstract}

\section{Introduction}

Antimicrobial resistant bacteria and associated illnesses are generally associated with, and attributed to, clinical use (or misuse) of antimicrobial drugs in humans. However, administration of antimicrobials for veterinary applications accounts for roughly $80 \%$ of total usage in the United States [1,2]. In 2015 approximately 15.58 million $\mathrm{kg}$ of antimicrobials approved for use in food producing animals were sold in the United States, reflecting a 22\% increase in sales and distribution since 2009 [3]. Worldwide, antimicrobial use in food-producing animals is expected to increase from 63,000 tons in 2010 to 105,500 tons of antimicrobials in 2030, a $67 \%$ increase over 20 years [4]. Extensive use of antimicrobials in agriculture could represent a potentially significant source of ARB which could continue to increase with growing demands for animal protein worldwide [4-9]. Antimicrobials administered to livestock are often incompletely metabolized, resulting in release of both the parent compound and associated metabolites into the environment where they can be dispersed by wind, runoff, and land application $[6,7,10-$ 14]. Depending on the antimicrobial entity, $30-90 \%$ of the dose can be excreted as the parent compound in urine, and up to $75 \%$ may be excreted in manure. Additionally, some reactive metabolites can be converted back to the parent compound once in the environment via bacterial metabolic processes [15]. This is significant because gut bacteria are shed from animals via feces at a rate of approximately $10^{11} \mathrm{CFU}$ (colony forming unit) per gram of fecal material [16]. Thus, antimicrobials used in livestock not only exert positive selective pressures in commensal microbial populations, but also in excretaladen pen floor environments $[6,8,17,18]$.

\section{Journal of}

Veterinary Science \& Medicine

\author{
Thompson KN, Wooten KJ, Hensley LL, Smith $\mathrm{PN}^{*}$ and \\ Mayer GD \\ Department of Environmental Toxicology, Texas Tech University, \\ USA \\ *Address for Correspondence \\ Smith PN, Department of Environmental Toxicology, Texas Tech \\ University, Lubbock, TX, USA, Tel no: (806) 834-6180, Email: phil. \\ smith@ttu.edu \\ Submission: 23 November, 2018 \\ Accepted: 26 December, 2018 \\ Published: 28 December, 2018 \\ Copyright: () 2018 Smith PN, et al. This is an open access article \\ distributed under the Creative Commons Attribution License, which \\ permits unrestricted use, distribution, and reproduction in any medium, \\ provided the original work is properly cited.
}

Recently published data indicate that bacterial communities harboring antimicrobial resistance determinants occur on fugitive PM collected downwind of beef cattle feed yards [12], and by extension, that airborne PM is a dissemination route for ARB to the surrounding environment. Because only a very small proportion of viable inhabitants in any environmental sample can be successfully cultivated in laboratory settings, the study was based on 16S DNA sequence analysis to gain broader understanding of bacterial community structures associated with airborne PM [12]. However, 16S DNA sequence analysis cannot differentiate between DNA derived from viable and non-viable bacteria. Therefore, the narrowly focused objectives of this study were to utilize culture-based methods to determine whether bacteria on fugitive PM collected near cattle feeding operations were viable, and to determine whether any successfully cultured bacteria were resistant to antimicrobials.

\section{Materials and Methods}

\section{Particulate matter collection}

To assess bacterial viability we collected PM samples downwind from eight and upwind from five beef cattle feed yards, located within a 200-mile radius of Lubbock, TX, with holding capacities ranging from 20,000-50,000 head. Each PM sample was collected adjacent to feed yard boundaries in the late afternoon, near dusk, when cattle are most active and during the period of peak PM suspension [19]. A portable high-volume air sampler (Hi-Q Environmental Products; Hi-Q CF-902) was placed on a stable platform facing into the wind, 1-2 $\mathrm{m}$ above the ground and approximately $5-10 \mathrm{~m}$ from the boundary of the feed yard to collect PM onto a four-inch diameter glass fiber filter (Hi-Q Environmental Products). After sampling, filters were placed in sterile, air-tight containers and transported to the laboratory.

\section{Microbial cultures}

Particulate matter was used to inoculate various culture broths and isolation agars to assess microbial viability and antimicrobial resistance on both upwind and downwind samples; however, isolates were only derived and identified from downwind samples because we were not readily able to culture ARB from upwind samples. Isolation of bacteria began with expansion of PM-bound bacteria in generic Tryptic Soy Broth (TSB). Expansion took place in three different 
Citation: Thompson KN, Wooten KJ, Hensley LL, Smith PN, Mayer GD. Viable Antimicrobial Resistant Bacteria are Transported from Cattle Feed Yards via Aerosolized Particulate Matter. J Veter Sci Med. 2018;6(2): 4.

ISSN: $2325-4645$

Table 1: Viable aerobic, microaerophilic, and anaerobic bacteria associated with airborne PM downwind of cattle feed yards. Isolates were identified based upon comparative 16S sequence identity to those listed in the greengenes database (Lawrence and Berkley National Lab, 2011), SILVA rRNA database or NCBI bacterial BLAST. Isolates were identified to the closest genus in many cases.

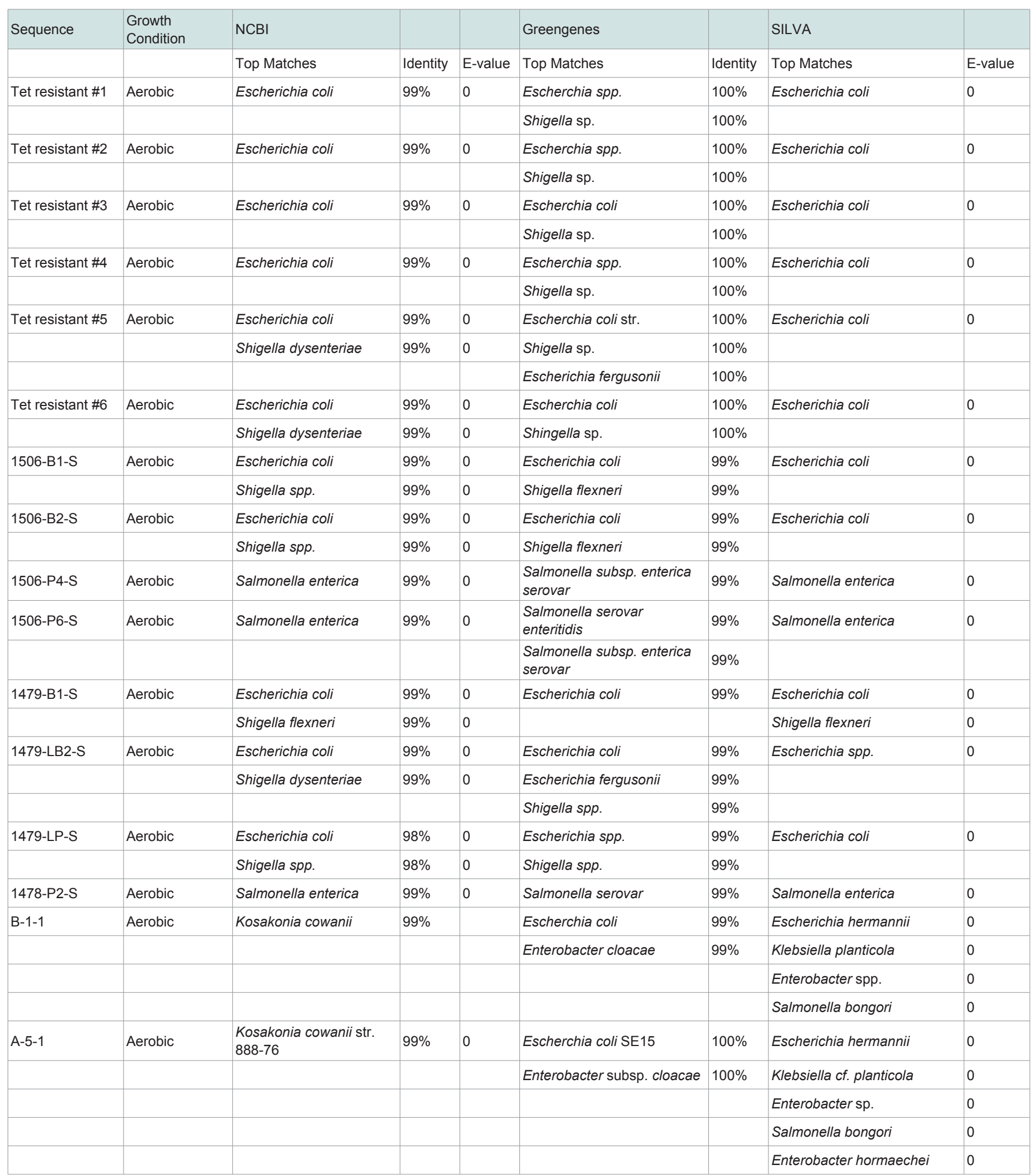


Citation: Thompson KN, Wooten KJ, Hensley LL, Smith PN, Mayer GD. Viable Antimicrobial Resistant Bacteria are Transported from Cattle Feed Yards via Aerosolized Particulate Matter. J Veter Sci Med. 2018;6(2): 4.

ISSN: $2325-4645$

\begin{tabular}{|c|c|c|c|c|c|c|c|c|}
\hline C-4-5 & Aerobic & Staphylococcus arlettae & $98 \%$ & 0 & Staphylococcus spp. & $98 \%$ & Streptococcus spp. & 0 \\
\hline$B-4-3$ & Aerobic & Bacillus spp. & $99 \%$ & 0 & Bacillus spp. & $99 \%$ & Bacillus spp. & 0 \\
\hline B-3-2 & Aerobic & Bacillus spp. & $99 \%$ & 0 & Bacillus spp. & $99 \%$ & Bacillus spp. & 0 \\
\hline B-5-2 & Aerobic & Staphylococcus hyicus & $98 \%$ & 0 & Staphylococcus sp. & $96 \%$ & Staphylococcus spp. & 0 \\
\hline \multirow[t]{4}{*}{ B-5-6 } & Aerobic & Entrobacter cloacae & $99 \%$ & 0 & Enterobactercloacae & $99 \%$ & Enterobacter spp. & 0 \\
\hline & & Klebsiella oxytoca & $99 \%$ & 0 & Klebiella oxytoca & $99 \%$ & Leclercia spp. & 0 \\
\hline & & & & & & & Pantoea sp. & 0 \\
\hline & & & & & & & Enterobacter cloacae & 0 \\
\hline $1430-4-3-A$ & Anaerobic & Clostridium butyricum & $99 \%$ & 0 & Clostridium butyricum & $99 \%$ & Clostridium spp. & 0 \\
\hline $1430-5-4-A$ & Anaerobic & $\begin{array}{l}\text { Clostridium } \\
\text { saccharolyticum }\end{array}$ & $97 \%$ & 0 & Clostridium xylanolyticum & $99 \%$ & Clostridium spp. & 0 \\
\hline 1439-2-1-A & Anaerobic & Entrococcus hirae & $99 \%$ & 0 & & & Enterococcus hirae & 0 \\
\hline $1450-4-2-A$ & Anaerobic & Clostridium butyricum & $99 \%$ & 0 & Clostridium butyricum & $99 \%$ & Clostridium butyricum & 0 \\
\hline $1493-1-2-A$ & Anaerobic & Streptococcus spp. & $99 \%$ & 0 & Streptococcus spp. & $99 \%$ & $\begin{array}{l}\text { Streptococcus salivarius } \\
\text { subsp. Salivarius }\end{array}$ & 0 \\
\hline $1493-5-2-A$ & Anaerobic & Clostridium spp. & $98 \%$ & 0 & & & Clostridium butyricum & 0 \\
\hline $1493-5-6-A$ & Anaerobic & Clostridium spp. & $99 \%$ & 0 & Clostridium butyricum & $99 \%$ & Clostridium butyricum & 0 \\
\hline \multirow[t]{2}{*}{$1506-2-5-A$} & Anaerobic & Escherichia coli & $99 \%$ & 0 & Escherichia coli & $99 \%$ & Escherichia spp. & 0 \\
\hline & & Shigella dysenteriae & $99 \%$ & 0 & Shigella spp. & $99 \%$ & & \\
\hline $1522-3-5-A$ & Anaerobic & $\begin{array}{l}\text { Enterococcus } \\
\text { casseliflavus }\end{array}$ & $98 \%$ & 0 & Enterococcus spp. & $99 \%$ & Enterococcus casseliflavus & 0 \\
\hline 1493-1-1-C & Microaerophilic & Bacillus spp. & $99 \%$ & 0 & Bacillus amyloliquefaciens & $99 \%$ & Bacillus spp. & 0 \\
\hline \multirow[t]{3}{*}{ 1506-1-6-C } & Microaerophilic & Klebsiela oxytoca & $97 \%$ & 0 & Enterobacter cloacae & $99 \%$ & Klebsiella oxytoca & 0 \\
\hline & & Enterobacter spp. & $98 \%$ & 0 & Klebsiella oxytoca & $99 \%$ & & \\
\hline & & & & & Pantoea spp. & $99 \%$ & & \\
\hline \multirow[t]{2}{*}{ 1506-3-3-C } & Microaerophilic & Paenibacillus alvei & $94 \%$ & 0 & Paenibacillus spp. & $98 \%$ & Paenibacillus spp. & 0 \\
\hline & & & & & Bacillus tipchiralis & $98 \%$ & Bacillus spp. & 0 \\
\hline $1450-2-3-C$ & Microaerophilic & Bacillus thuringiensis spp. & $99 \%$ & 0 & Bacillus spp. & $99 \%$ & Bacillus thuringiensis & 0 \\
\hline
\end{tabular}

oxygen concentrations to identify aerobic, microaerophilic, and anaerobic taxa. A $1 \mathrm{~cm}^{2}$ piece of filter material was placed in a $15 \mathrm{ml}$ tube containing $5 \mathrm{ml}$ of TSB and shaken at $225 \mathrm{rpm}$ at $37^{\circ} \mathrm{C}$ overnight in a MaxQ 400 incubator (ThermoScientific, Waltham, MA, USA). Bacteria were then placed on Tryptic Soy Agar (TSA) plates for aerobic incubation, Brucella agar for microaerophilic incubation, or anaerobic agar. Aerobic cultures were also propagated on Salmonella selective plates (CHROMagar Salmonella, VWR) for identification of Salmonella. Anaerobic conditions were created using BD GasPak EZ Container Systems with Anaerobe Sachets (VWR). The chamber was evaluated for anaerobic conditions using Anaerobic Indicator Strips (VWR). Microaerophilic conditions used the same chamber as anaerobic conditions but used Campy Sachets (VWR) to create a low oxygen environment. Once mixed cultures of aerobic, anerobic and microaerophilic bacteria were propagated, plating densities were adjusted to isolate single colonies of bacteria for identification.

\section{DNA extraction and analysis}

DNA was extracted from several bacterial isolates from each oxygen condition using a MoBio Power Soil DNA Isolation Kit according to manufacturer's directions with modifications including; heating solutions $\mathrm{C} 1$ and $\mathrm{C} 6$ to $65^{\circ} \mathrm{C}$, allowing the samples to vortex for 20 minutes to increase degradation of the cell membranes, and allowing one minute for solution C6 to mix with the DNA on the filter before centrifugation. DNA quantity was approximated spectrophotometrically using a NanoDrop 1000 spectrophometer (ThermoScienfitic). To identify cultured bacteria, the V1-V3 region of $16 \mathrm{~S}$ rRNA loci were amplified by PCR. All PCR primers used in this study were previously published (see Supplemental Material, Table S1). Amplification was performed in $25 \mu$ of GoTaq Flexi PCR Mix (Promega, Madison, WI, USA) following the manufacturer's instructions. PCR cycling consisted of an initial denaturation for two minutes at $95{ }^{\circ} \mathrm{C}$, followed by 34 cycles comprised of one minute at $95^{\circ} \mathrm{C}$, then $54^{\circ} \mathrm{C}$ for thirty seconds and $72{ }^{\circ} \mathrm{C}$ for forty-five seconds. After cycle completion, elongation was allowed to proceed for an additional 5 minutes at $72{ }^{\circ} \mathrm{C}$. All PCR products were stored at 4 ${ }^{\circ} \mathrm{C}$ until further analysis. Reactions were performed on a Peltier Thermal Cycler (MJ Research, Hercules, CA, USA). Amplicons were then isolated from $1 \%$ agarose gels (VWR) using QAIquick DNA Extraction Kits (Qiagen Inc, Valencia, CA, USA). Purified amplicons were sequenced using the amplification primers by sanger sequencing at the University of Maine DNA sequencing facility. Sequences of $16 \mathrm{~S}$ amplicons were blasted against the greengenes database curated by Lawrence and Berkley National Laboratory [20], NCBI Microbial Nucleotide BLAST [21-24], and the SILVA Ribosomal database [25, $26]$ to obtain the taxonomy of each bacterial isolate. 
Citation: Thompson KN, Wooten KJ, Hensley LL, Smith PN, Mayer GD. Viable Antimicrobial Resistant Bacteria are Transported from Cattle Feed Yards via Aerosolized Particulate Matter. J Veter Sci Med. 2018;6(2): 4.

ISSN: $2325-4645$

Table 2: Antibiotic resistance of the bacteria grown in each of the four different growth conditions. Five antibiotics were tested, tetracycline, streptomycin, chloramphenicol, erythromycin, and novobiocin. Each condition is listed as either resistant $(R)$ to the antibiotic or susceptible (S) and has the number of feed yards that exhibited resistance.

\begin{tabular}{|l|l|l|l|}
\hline Antimicrobial Resistance - Downwind & Growth Condition & & \\
\hline Anitbiotic & Aerobic & Anaerobic & Salmonella \\
\hline Tetracycline & $\mathrm{R}(3 / 8)$ & $\mathrm{R}(3 / 8)$ & $\mathrm{S}(0 / 2)$ \\
\hline Streptomycin & $\mathrm{R}(8 / 8)$ & $\mathrm{R}(7 / 8)$ & $\mathrm{S}(0 / 2)$ \\
\hline Chloramphenicol & $\mathrm{S}(0 / 8)$ & $\mathrm{R}(4 / 8)$ & $\mathrm{S}(0 / 2)$ \\
\hline Erythromycin & $\mathrm{R}(1 / 8)$ & $\mathrm{R}(4 / 8)$ & $\mathrm{S}(0 / 5)$ \\
\hline Novobiocin & $\mathrm{S}(0 / 8)$ & $\mathrm{S}(0 / 8)$ & $\mathrm{R}(0 / 2)$ \\
\hline Antimircobial Resistance - Upwind & Growth Condition & & \\
\hline Antibiotic & Aerobic & & \\
\hline Tetracycline & $\mathrm{S}(0 / 5)$ & & \\
\hline Streptomycin & $\mathrm{S}(0 / 5)$ & \\
\hline Chloramphenicol & $\mathrm{S}(0 / 5)$ & \\
\hline Erythromycin & $\mathrm{S}(0 / 5)$ & \\
\hline Novobiocin & $\mathrm{S}(0 / 5)$ & \\
\hline
\end{tabular}

\section{Results and Discussion}

\section{Viable bacteria}

Using these methods we were able to culture and identify viable bacteria that reside on airborne PM emerging from beef cattle feed yards. Of the top ten phyla of bacteria sequenced in [12], we were able, with limited culture effort, to propagate strains from Firmicutes and Proteobacteria. The limited number of cultured genra was not unexpected given that only about $1 \%$ of environmental bacterial are culturable [27]. Furthermore, only three distinct culture agars were used in this study; thus, it is probable that additional genera would have been cultured if additional growth media formulations were utilized. Genera of easily cultured aerobic bacteria from downwind fugitive PM included Escherchia, Shigella, Enterobacter, Staphylococcus, Bacillus and Klebsiella (Table 1). Additionally, Salmonella was cultured from PM collected downwind of two of the eight feed yards. Microaerophilic and anaerobic cultures contained bacteria from the generas of Clostridium, Enterococcus, Streptococcus, Pantoea and Paenibacillus (Table 1). Though it has been suggested that failure to culture gram negative bacteria from airborne particulates is a result of desiccation and/or irradiation [28], culture efforts in this study resulted in the propagation of a diverse array of gram negative taxa from airborne PM samples downwind of cattle feed yards. Many of the identified isolates from aerosolized PM were common bovine gut microbiome inhabitants.

\section{Antimicrobial resistance}

Antimicrobial resistance was assessed in mixed cultures of aerobic, anaerobic and microaerophilic cultures by evaluating zones of inhibition in classic disc diffusion tests (Kirby-Bauer) [29], where we evaluated resistance to the following broad-spectrum antimicrobials; tetracycline, streptomycin, chloramphenicol, erythromycin and novobiocin (Ward's Natural Science, Rochester, NY, USA). Since mixed cultures were propagated to identify antimicrobial resistance in fugitive PM, only broad-spectrum antimicrobial compounds targeting gram-positive and gram-negative bacteria were utilized. Salmonella strains used in this portion of the study were isolates, since identification using selective plates was first required. Additionally, aerobic bacteria were cultured in broth containing $50 \mathrm{ug} / \mathrm{mL}$ tetracycline and plated for isolation on agar containing $50 \mathrm{ug} / \mathrm{mL}$ tetracycline. Tetracycline-resistant strains propagated in this manner were then partially sequenced and identified as E. coli. At least one isolate cultured from feed yard-derived PM demonstrated resistance to all antimicrobials evaluated. Although some antimicrobial resistant bacteria were expected to be cultured from our upwind samples, none were identified (Table 2). Downwind aerobicallycultured samples yielded isolates that were resistant to one or more antimicrobials; tetracycline, streptomycin, or erythromycin. This is not surprising, as the cultures were dominated by $E$. coli which readily uptake and transfer environmental DNA. Microaerophilic bacteria, in which resistance genes are often plasmid-encoded, were resistant to streptomycin and erythromycin. Anaerobic bacteria exhibited resistance to the widest range of antimicrobial compounds with at least one isolate exhibiting resistance to all antimicrobials examined except novobiocin. Surprisingly, at least one isolate of Salmonella demonstrated resistance to novobiocin (Table 2). Mixed cultures of bacteria exhibited resistance to several broad spectrum antimicrobial compounds. This suggests that a spectrum of antibiotic resistant bacteria inhabit PM collected downwind of cattle feed yards, and further implicates feed yard-derived airborne $\mathrm{PM}$ as a transport mechanism facilitating environmental dissemination of ARB.

\section{Conclusion}

Since several strains of viable antimicrobial resistant bacteria reside within feed yard pen material, aerosolization of these moieties could result in respiratory exposure of the herd, feed yard workers and surrounding communities to potentially pathogenic and antibiotic resistant bacteria [19,30]. In light of recent evidence that free-living bacteria retain antibiotic resistance cassettes without the presence of a selective pressure and that this retention comes at no physiological cost to the bacterium [31], the potential for resistance determinants to be spread laterally to other free-living bacteria is probable. This increases risk of localized antibiotic resistant bacterial infections and adds to the spread of ARB, especially in environments similar to West Texas where long-range transport of aerosolized particles is exacerbated by frequent, powerful wind events $[19,31]$.

\section{References}

1. DeVincent SJ, Viola C (2006) Deliberations of an Advisory Committee regarding priorities, sources, and methods for collecting animal antimicrobial use data in the United States. Prev Vet Med 73: 133-151. 
Citation: Thompson KN, Wooten KJ, Hensley LL, Smith PN, Mayer GD. Viable Antimicrobial Resistant Bacteria are Transported from Cattle Feed Yards via Aerosolized Particulate Matter. J Veter Sci Med. 2018;6(2): 4.

ISSN: $2325-4645$

2. Food Administration D (2016) Summary Report: on antimicrobials sold or distributed for use in food-producing animals. pp. 1-67.

3. Food and Drug Administration, Department of Health and Human Servies (2015-2017) Summary Report on Antimicrobials Sold or Distributed for Use in Food-Producing Animals. pp. 1-58.

4. Van Boeckel TP, Brower C, Gilbert M, Grenfell BT, Levin SA, et al. (2015) Global trends in antimicrobial use in food animals. Proc Natl Acad Sci USA 112: $5649-5654$

5. Dungan RS (2010) BOARD-INVITED REVIEW: Fate and transport of bioaerosols associated with livestock operations and manures. J of Animal Sci 88: 3693-3706.

6. Gilchrist MJ, Greko C, Wallinga DB, Beran GW, et al. (2006) The potential role of concentrated animal feeding operations in infectious disease epidemics and antibiotic resistance. Environ Health Perspect 115: 313-316.

7. Khan SJ, Roser DJ, Davies CM, Peters GM, Stuetz RM, et al. (2008) Chemical contaminants in feedlot wastes: Concentrations, effects and attenuation. Environ Intern 34: 839-859.

8. Levy SB, Marshall B (2004) Antibacterial resistance worldwide: causes, challenges and responses. Nat Med 10: 122-129.

9. Phillips I (2003) Does the use of antibiotics in food animals pose a risk to human health? A critical review of published data. J Antimicrob Chem 53: 28-52.

10. Ji X, Shen Q, Liu F, Ma J, Xu G, et al. (2012) Antibiotic resistance gene abundances associated with antibiotics and heavy metals in animal manures and agricultural soils adjacent to feedlots in Shanghai; China. J Hazard Mater 235-236: 178-185.

11. Joy SR, Bartelt-Hunt SL, Snow DD, Gilley JE, Woodbury BL, et al. (2013) Fate and Transport of Antimicrobials and Antimicrobial Resistance Genes in Soil and Runoff Following Land Application of Swine Manure Slurry. Environ Sci Technol 47: 12081-12088.

12. McEachran AD, Blackwell BR, Hanson JD, Wooten KJ, Mayer GD, et al. (2015) Antibiotics, Bacteria, and Antibiotic Resistance Genes: Aerial Transport from Cattle Feed Yards via Particulate Matter. Environ Health Perspect 123: 337-343.

13. Singer RS, Reid-Smith R, Sischo WM (2006) Stakeholder position paper: Epidemiological perspectives on antibiotic use in animals. Prev Vet Med 73 153-161.

14. Wegener HC (2003) Antibiotics in animal feed and their role in resistance development. Curr Opin Microbiol 6: 439-445.

15. Sarmah AK, Meyer MT, Boxall AB (2006) A global perspective on the use, sales, exposure pathways, occurrence, fate and effects of veterinary antibiotics (VAs) in the environment. Chemosphere 65: 725-759.
16. Dowd SE, Callaway TR, Wolcott RD, Sun Y, McKeehan T, et al. (2008) Evaluation of the bacterial diversity in the feces of cattle using 16S rDNA bacterial tag-encoded FLX amplicon pyrosequencing (bTEFAP). BMC Microbiol 8: 125 .

17. Allen HK, Donato J, Wang HH, Cloud-Hansen KA, Davies J, et al. (2010) Call of the wild: antibiotic resistance genes in natural environments. Nat Rev Micro 8: $251-259$

18. He LY, Liu YS, Su HC, Zhao JL, Liu SS, et al. (2014) Dissemination of Antibiotic Resistance Genes in Representative Broiler Feedlots Environments: Identification of Indicator ARGs and Correlations with Environmental Variables. Environ Sci Technol 48: 13120-13129.

19. Purdy CW, Clark RN, Straus DC (2007) Analysis of Aerosolized Particulates of Feedyards Located in the Southern High Plains of Texas. Aeros Sci Tech 41: 497-509

20. DeSantis TZ, Hugenholtz P, Larsen N, Rojas M, Brodie EL, et al. (2006) Greengenes, a chimera-checked 16S rRNA gene database and workbench compatible with ARB. Appl Environ Microbiol 72: 5069-5072.

21. Altschul SF, Gish W, Miller W, Myers EW, Lipman DJ (1990) Basic local alignment search tool. J Mol Biol 215: 403-410.

22. Boratyn GM, Camacho C, Cooper PS, Coulouris G, Fong A, et al. (2013) BLAST: a more efficient report with usability improvements. Nucleic Acids Res 41: 29-33.

23. Madden T, (McEntyre J, Ostell J. eds) (2002-2005) The BLAST: sequence analysis tool. In The NCBI Handbook. US. National Library of Med.

24. NCBI Resource Coordinators (2012) Database resources of the National Center for Biotechnology Information. Nucleic Acids Res 41: D8-D20.

25. Pruesse E, Quast C, Knittel K, Fuchs BM, Ludwig WG, et al. (2007) SILVA a comprehensive online resource for quality checked and aligned ribosomal RNA sequence data compatible with ARB. Nucleic Acids Res 35: 7188-7196.

26. Quast C, Pruesse E, Yilmaz P, Gerken J, Schweer T, Yarza P, Peplies J, Glöckner FO (2012) The SILVA ribosomal RNA gene database project: improved data processing and web-based tools. Nucleic Acids Res 41: D590-D596.

27. Amann RI, Ludwig W, Schleife KH (1995) Phylogenetic identification and in situ detection of individual microbial cells without cultivation. Microbiol Rev 59: $143-169$

28. Cole NA, Todd R, Auvermann B, Parker D (2008) Auditing and Assessing Air Quality in Concentrated Feeding Operations. USDA-ARS 24: 1-23.

29. Dickert H, Machka K, Braveny I (2017) The Uses and Limitations of Disc Diffusion in the Antibiotic Sensitivity Testing of Bacteria. Infection 9: 18-24.

30. Castillo Neyra R, Vegosen L, Davis MF, Price L, Silbergeld EK (2012) Antimicrobial-resistant Bacteria: An Unrecognized Work-related Risk in Food Animal Production. Saf Health Work 3: 85-91.

31. Stout JE (2001) Dust and environment in the Southern High Plains of North America J Ari Environ 47: 425-441.

\section{Acknowledgement}

Thank you to the University of Maine DNA sequencing facility for Sanger sequencing. 